\title{
Azerbaycan Atabeyleri İldenizlilerin Kafkasya Politikası Ve Gürcü Krallığı
}

\author{
Hüseyin Kayhan*
}

\section{Özet}

Büyük Selçuklu Devleti'nin 1040-1092 yılları arasında tahtta bulunan ilk sultanlarının baskılarından sonra kendilerini toparlayan Gürcü kralları, ülkelerine yerleştirdikleri Kıpçaklardan aldıkları desteklerle XII. yüzyılın başlarından itibaren Türk topraklarına yoğun saldırılarda bulundular. Bunları durdurmada ve karşı saldırılarla etkisiz hale getirmede son Selçuklu sultanları başarılı olamadılar. 1141-1225 tarihleri arasında Azerbaycan'da hâkim olan İldenizlilerin ilk atabeyleri Kafkaslarda güvenliği sağladılar. Ancak, 1194'te Irak Selçukluları Devleti'nin ortadan kalkması sonrasında Azerbaycan'ı yöneten atabeyler başarılı olamadılar. Durdurulamayan Gürcü saldırıları yaygınlaşarak İran'ın batısından Güney-doğu Anadolu'ya kadar uzanan sahalarda etkili oldu. Son İldenizli atabeyleri Gürcü krallarını politik manevralarla durdurmaya çalıştılarsa da başarılı olamadılar.

Anahtar Kelimeler: Kafkaslar, Gürcü Krallığı, Azerbaycan Atabeyleri İldenizliler, Irak Selçukluları Devleti, Doğu Anadolu Türk Beylikleri.

\section{Caucasian Policy of Ildenizid Atabegs in Azerbaijan and the Kingdom of Georgia}

\section{Abstract}

Recovering themselves after the pressures of the early Great Seljuk sultans who were on the throne between 1040 and 1092, Georgian kings launched intensive attacks on Turkish territories starting from the beginnings of the $12^{\text {th }}$ century as they received help from the Kipchaks they had settled in their kingdom. The last Seljuk sultans did not succeed in stopping Georgian attacks and launching counter attacks against the Kingdom of Georgia. The first atabegs of Ildenizids, who ruled in Azerbaijan between the years 1141 and 1225 , provided security in the Caucasus. However, following the fall of the Seljuk Sultanate of Iraq in 1194, the atabegs who ruled Azerbaijan were

\footnotetext{
* Yrd. Doç. Dr., Çanakkale Onsekiz Mart Üniversitesi, Fen-Edebiyat Fakültesi, Tarih Bölümü, hukaturk@hotmail.com. (ORCID ID: 0000-0001-9036-3312).

(Makale Gönderim Tarihi: 14.05.2017, Makale Kabul Tarihi: 11.08.2017)
}

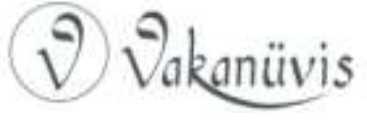


not successful. Unstoppable Georgian attacks became widespread and these were effective in areas ranging from western Iran to south-eastern Anatolia. The last Ildenizid atabegs tried to stop Georgian kings with political maneuvers, but they were not successful.

Keywords: Caucasus, Kingdom of Georgia, Ildenizid Atabegs of Azerbaijan, Seljuk Sultanate of Iraq, Eastern Anatolian Turkish Principalities.

\section{Giriş}

Selçukluların 1040'da İran'da devlet kurmalarından sonra Ortadoğu'ya muazzam bir Türkmen göçü yaşanmıştı. Bu konar-göçer Türkmenler, XI. yüzyılın sonlarında Kafkasya'da Azerbaycan ile Gürcistan'ın bir kısmını uğrak yeri olarak kullanıyorlardı. Gürcü tarihi Kartlis Çovreba'nın belirttiğine göre, Türkler 1110 yılına kadar Tiflis civarı, Rustav, Somakhet, Şamşvilde ve Agarani topraklarını işgal edip, sayısız at, koyun, katır ve deve sürüleri ile Ilti ve İor kıyılarında yerleşmişlerdi. Bunlar ilkbaharda Somakhet ve Ararat Dağlarındaki yaylaklarına çekilmekteydiler. ${ }^{1}$

Sultan Melikşah'ın 1092'de ölümü ve sonrasında yaşanan taht mücadeleleri Selçuklu Devleti'nin gücünü önemli ölçüde sarstığı için Kral IV. David'in (1089-1125) Gürcistan'ın yönetimini üstlenmesi ile birlikte Kafkaslarda güç mücadelesi Türklerin aleyhine değişmeye başladı. Gürcü Krallığı, XII. yüzyılda Doğu Anadolu ve Azerbaycan'daki Türk topraklarına yaptığı saldırılarla, buralarda yaşayan Hıristiyanların gözünde XI. yüzyılın ortalarındaki Bizans'ın konumuna yerleşti. ${ }^{2}$

1110 yılında IV. David'in komutanları Teodor, Orbelyanlı Yoane ve Ebulets'in yardımlarıyla Şamşvilde'yi Türklerin elinden aldı. ${ }^{3}$ Saldırılarını Gence ve çevresine kadar ilerletti. ${ }^{4}$ Bunun üzerine Sultan Muhammed

\footnotetext{
1 Kartlis Çovreba, Gürcistan Tarihi (Eski Çağlardan 1212 Yılına Kadar), çev. H. Andreasyan, Ankara, 2003, 316; W. E. D. Allen, A History of The Georgian People, London, 1932, 98.

2 i. Tellioğlu, "Orta Çağ’da Türk-Gürcü münasebetlerini şekillendiren faktörler”, 38. Icanas Uluslararası Asya ve Kuzey Afrika Çalışmaları Kongresi (10-15 Eylül 2007 Ankara), Doğubilim Çalışmaları, Bildiriler, VI, Ankara, 2009, 3081.

${ }^{3}$ Çovreba, a.g.e., s. 316-317.

${ }^{4}$ Hüseynî, Ahbârü’d-Devleti's-Selçukiyye, çev. N. Lugal, Ankara, 1943, 57.
} 
Tapar bir ordu yollayarak Gürcü kralını yenilgiye uğratıp, bölgenin emniyetini sağladı (503/1110). ${ }^{5}$

Kral David, 1115 yılında Rustav'ı ele geçirdi. ${ }^{6}$ Bu olay, burada yaşayan Türkler için büyük bir darbe oldu. David, ertesi yıl, kışın çok sert geçeceğini hesaplayarak, dağlardaki yaylaklarından inip, Tao (Erzurum çevresi) bölgesinde kışlaklarına çekilen oldukça kalabalık sayıdaki Türkmen gurubunun üzerine ani bir saldırıda bulunarak, onları yenilgiye uğrattı (Mart 1116). ${ }^{7}$ Saldırılarına devam eden David, 1117'de Eğriçay üzerinde bulunan Giş kalesini, 1118'de de Somakhet'in merkezi Lori kalesini ele geçirdi. ${ }^{8}$

Türkmenleri şaşırtmak için, Abhazya'ya gider gibi yapan David, Türkmenlerin kışı geçirmek için Botora'ya geçmelerini bekleyerek, 14 Şubat 1120 tarihinde aniden saldırıya geçip, Türkmenleri korkunç bir katliama tâbi tuttu. Buradan Şirvan'a yürüdü ve Kabala şehrini aldıktan sonra Krabia, Licuta, Şişlanta ile Kurdevan'a kadar olan yerleri yağmalayarak, ganimetleriyle Kartli'ye geri döndü (Mayıs 1120). ${ }^{9}$

Kral David, 1121 yılı kış mevsiminde çok kar yağmasının etkisiyle tedbirsizce hareket ederek Mtkuar kıyılarına gelen Türkmenleri gafil avlamak için Likh Dağı üzerinde bir geçit açtırıp saldırdı ve yenilgiye uğrattı (Mart 1121). Aynı yılın Haziran ayında, Arabya ve Berdea'yı tahrip eden David, ilkbaharda oraya gelerek yaylaklarına çekilen Türkmenleri de bozguna uğrattı. ${ }^{10}$

Kral David, dört asırdan beri Müslümanların elinde bulunan Tiflis'i sıkıştırarak yıllık 10 bin dinar vergiye bağladı. ${ }^{11}$

\footnotetext{
${ }^{5}$ Hüseynî, a.g.e., s. 57; i̇bnu'l-Kalânisî, Zeyli Târîhi Dimaşk, Nşr. H. F. Amedroz, Beyrut, 1908, 168.

${ }^{6}$ Çovreba, a.g.e., s. 317.

7 Çovreba, a.g.e., s. 317; M. F. Kırzıoğlu, Yukarı-Kür ve Çoruk Boyları'nda Kıpçaklar, Ankara, 1992,113.

${ }^{8}$ Çovreba, a.g.e., s. 318; A. Manvelichvili, Histoire de Géorgie, Paris, 1951, 167.

9 Çovreba, a.g.e., s. 321; O. Turan, Selçuklular Tarihi ve Türk-Islâm Medeniyeti, İstanbul, 1980, 270.

${ }^{10}$ Çovreba, a.g.e., s. 321.

11 İbnu'l-Ezrak, Târihi Meyyâfârikîn ve Âmid, çev. A. Savran, Erzurum, 1992, 33-34; V. Minorsky, "Causacia in the History of Mayyafarikin", BSOAS, VIII/1, 1949, 32; A. Sevim, "Artukoğlu ilgâzi", Belleten, XXVI/104, 1962, 683.
} 
Müslüman halkın şikâyeti üzerine, Irak Selçukluları Sultanı Mahmud, kardeşi Melik Tuğrul, Artukoğlu ilgâzi ve Bitlis ile Erzen hükümdarı Togan Arslan'ı Gürcistan seferiyle görevlendirdi. ${ }^{12}$ Kral David, oğlu Dimitri ile birlikte, büyük bir orduyla dağ geçitlerini kapatıp, ilgâzi'ye ani bir saldırıda bulunarak yenilgiye uğrattı (18 Ağustos 1121). ${ }^{13}$ Kral David, bu zaferinden sonra, Tiflis üzerine yöneldi ve şehri kuşatarak ele geçirdi (14 Ağustos 1122). ${ }^{14}$ ilerlemesine devam eden Kral David, aynı yıl Gence üzerine yürüyerek, şehrin çevresini yağmaladı. ${ }^{15}$

Sultan Mahmud, Gürcülere haddini bildirmek üzere sefere çıktı (1123). Ordusuyla birlikte Şirvân'a varıp Gürcü kralına bir mektup göndererek onu savaşa teşvik etti. íki ordu arasında bir savaş kaçınılmaz hale gelmişken, geceleyin Kıpçaklar ile arasında sebebini bilmediğimiz bir anlaşmazlık ve kargaşanın çıkması üzerine savaşı göze alamayan Kral David geri çekildi. Sultan Mahmud, Gürcü ordusunu takip etmeyerek geri çekildi. ${ }^{16}$

Gürcü kralı, Mart 1124 tarihinde Kartli'ye girerek Dmanis şehrini aldı ve Nisan ayında Şaburan'da Selçukluların Derbend valisine saldırdı. Mayıs ayında Somakhet, Gagni, Terunakan, Kavazin, Norberd, Manasgomni ve Kalincakar kalelerini zaptetti. Haziran 1124 tarihinde

\footnotetext{
${ }^{12}$ ibnu'l-Ezrak, a.g.e., s. 34; íbnu'l-Esîr, el-Kâmil fít-Târîh, çev. A. Özaydın, A. Ağırakça, İslâm Tarihi, Ibnu'l-Esîr, el-Kâmil fi't-Târîh Tercümesi, İstanbul, 1987, X, 567.

${ }^{13}$ íbnu'l-Ezrak, a.g.e., s. 33-35; i̇bnu'l-Esîr, a.g.e., s. 567-568, Çovreba, a.g.e., s. $321-$ 322; Urfalı Mateos, Urfalı Mateos Vekayi-nâmesi (952-1136) ve Papaz Grigor'un Zeyli (1136-1162), çev. H. D. Andreasyan, Ankara, 1987, 268-270; Süryani Mihael, Vekayinâme, ikinci Kısım (1042-1195), Çev. H. D. Andreasyan, 1944 (TTK Kütüphanesi'nde bulunan basılmamış tercüme), 69; ibnu'l-Kalânisî, 204-205; Sıbt İbnu'I-Cevzî, Mir'atu'z-Zeman fi Târihi'l-A'yân, Yay. J. R. Jewett, Chicago, 1907, 62; Azîmî, Târîhu'l-Azîmî, Azîmî Tarihi (Selçuklular Dönemiyle ilgili Bölümler), Nşr. ve çev. A. Sevim, Ankara, 1988, 388; ibnu'I-Adîm, Zubdetu'l-Haleb min Târîhi Haleb, Nşr. S. Dahhan, Dimaşk, 1954, II, 199-200; V. Minorsky, "Tiflis", IA, XII/1, 267.

${ }^{14}$ ibnu'l-Ezrak, a.g.e., s. 36; Çovreba, a.g.e., s. 324; Sıbt, a.g.e., s. 62; Vardan Vartabet, Türk Fütûhatı Tarihi (889-1269), çev. H. D. Andreasyan, TSD, I, İstanbul, 1937, 195; M. F. Kırzıoğlu, a.g.e., s. 117; W. E. D. Allen, a.g.e., s. 98.

${ }^{15}$ ibnu'l-Ezrak, a.g.e., s. 37.

${ }^{16}$ Çovreba, a.g.e., s. 324-325; i̇bnu'l-Esîr, a.g.e., s. 615-616; el-Bundârî, Zubdeu'nNusra ve Nuhbetu'I-Usra, çev. K. Burslan, Irak ve Horasan Selçukluları Tarihi, İstanbul, 1943, 132-133; O. Turan, 271; V. Minorsky, "Tiflis", 267.
}

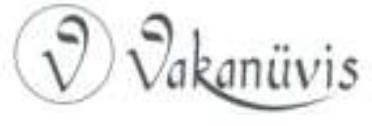


Şirvân'a girerek, Şirvânşah'ın Gülistan Sarayını ele geçirdi ve bütün bölgeyi Gürcülerin hâkimiyeti altına aldı. ${ }^{17}$

Ani Şeddâdî emîri Ebû'l-Esvâr, Ani'yi Garin emîrine satmak isteyince, şehirde bulunan Hıristiyan halk Kral David'i yardıma çağırdılar ve şehri ona teslim ettiler (20 Ağustos 1124). Kral David, seferlerine devam ederek Şamakya, Bigri kalesi ve Şirvân ülkesinin zaptedemediği diğer bölümleri ile Derbend, Dağıstan, Oltu, Dualet, Ciket ve Hazar Denizine kadar olan toprakları ele geçirdikten sonra 25 Ocak 1125 tarihinde öldü. ${ }^{18}$

Kral I. Dimitri (1125-1155), babası IV. David'in mücadelelerini devam ettirmişti. Azerbaycan ve Arrân bölgesinin valisi olan Atabeg Kara-sungur, Gürcü hücumlarına karşı koyarak, onlara darbeler indirmekteydi. Onun ordusu ile Fars ve Huzistan'da bulunduğu bir sırada durumdan faydalanan Gürcü ve Abhaz komutanı Ebuleth oğlu Yovane, ordusuyla Gence dolaylarına saldırarak binlerce insanı öldürmüş, ancak Karasungur yetişip, Gürcü ordusunu yenerek, geri püskürtmüştü (533/1138-39). Karasungur'un 535/1140-41'de ölümünden sonra, kendisi gibi Sultan Tuğrul'un kölelerinden Çavlı Candar bölgenin idaresini ele aldı. ${ }^{19}$ Çavlı Candar, Ekim-Kasım 1146 tarihinde öldükten ${ }^{20}$ sonra, iktâları olan Gence ve Arrân toprakları Hâcib Abdurrahman Toganyürek'e iktâ edildi. Bu komutan Emîr Hasbeg tarafından aynı yıl içerisinde öldürülünce ${ }^{21}$ Azerbaycan'ın idaresi Atabeg Şemseddin Illdeniz'in kontrolüne girdi.

Kafkaslarda bir başka siyasi yapı Müslüman Şirvanşahlar Devleti idi. Selçukluların ve ildenizlilerin Kafkasya'da tâbileri olan Şirvanşahlar hanedanı ve halkı İranlılaşmıştı ve bunların Gürcülerle evlilik bağları

\footnotetext{
${ }^{17}$ Çovreba, a.g.e., s. 324-325.

${ }^{18}$ Çovreba, a.g.e., s. 325-335; Vardan, a.g.e., s. 195-196; Urfalı Mateos, a.g.e., s. 279; V. Minorsky, Studies in Caucasian History, London, 1953, 84; O. Turan, Selçuklular Zamanında Türkiye Tarihi, İstanbul, 1984,165; W. E. D. Allen, 100.

${ }^{19}$ Bundârî, a.g.e., s. 174-175; Anili Samuel, Tables Chronologiques, Fr. tr. M. Brosset, Petersburg, 1876, II, 463; Kesrevîi-i Tebrizî, Şehr-i Yârân-ı Gumnâm, Tahran, 1307-1308, III, 73-74; F. Kırzıoğlu, Kars Tarihi, İstanbul, 1953, I, 384-393.

${ }^{20}$ Bundârî, a.g.e., s. 184-185; Hüseynî, a.g.e., s. 81-82; Râvendî, Râhatu's-Sudûr ve Âyeti's-Sûrûr, çev., A. Ateş, Râhatu's-Sudûr ve Âyeti's-Sûrûr (Gönüllerin Rahatı ve Sevinç Alâmeti), Ankara, 1957, I, 225-226; íbnu'l-Esîr, a.g.e., s. 118.

${ }^{21}$ ibnu'l-Esîr, a.g.e., XI, s.108; Bundârî, a.g.e., s. 196.
} 
vardı. Kuzeyde Derbend'e, güneyde Mugan'a ve güney-batıda Arran, Şeki ve Beylakan'a karşı saldırgan eğilimler gösteriyordu. Yerel Arap meliklerinin elindeki Derbend'in Gürcistan ile evlilik bağları vardı ve Şirvan'la düşmanca ilişkiler içindeydi. ${ }^{22}$

Kafkaslardaki savaşlar, geri planda yaşanan hareketliliği gözlerden saklamaktaydı. Burası ekonomik faaliyetlerin yoğun olduğu alanlardan birisi idi ve ticari faaliyetler durmaksızın devam etmekteydi. Gürcü Krallığı bu işin dışında imiş gibi bir görüntü vermekle birlikte, gerçek bunun tam tersi idi. Kral IV. David, 14 Ağustos 1122 tarihinde Tiflis'i ele geçirdikten sonra Kafkasya'nın bu önemli Müslüman şehrinin ticari önemini göz önünde bulundurarak Müslüman halkın şehirden ayrılmasını önlemek ve eski ticari faaliyetlerini devam ettirmelerini sağlamak için onlara güvenceler vermişti. Ticareti olumsuz yönde etkilememesi için önceden kullanılan İslâmi paraları tedavülde tuttu ve yeni bastırılacak paraları da bu yönde tasarladı. Vergilerin alımında da aynı yol takip edildi. Müslümanlardan daha az vergi alınması kararlaştırıldı. Bu cümleden olarak, Hıristiyan Gürcüler yıllık 5, Yahudiler 4, Müslümanlar ise sadece 3 dinar vergi vereceklerdi. ${ }^{23}$

Gürcü baskıları karşısında çaresiz kalan Gence, Tiflis ve Dmanis'teki Türkmen tacirler, mâteme bürünüp, ellerini, yüzlerini ve vücutlarını siyaha boyayarak, bütün Müslüman hükümdarlarına ve Irak Selçukluları sultanı Mahmud'a durumlarını anlatarak, Gürcülerin vakit geçirilmeden cezalandırılmasını istemişlerdi. ${ }^{24}$ Müslüman tüccarların bu hassasiyetlerini sadece dini ve milli amaçlarla açıklamak mümkün değildir. Şüphesiz Gürcülerin saldırıları sonucu Kafkasya'da güvenliğin ortadan kalkması ile ticari faaliyetlerinin bozulması da onları böyle bir harekete zorlamış olmalıydı.

Ani Şeddâdî emîri Ebû'I-Esvâr, Ani'yi 60 bin dinara Garin emîrine satmak isteyince, şehirde bulunan Hıristiyan halk buna tepki göstererek, Kral David'i yardıma çă̆ırmışlar ve şehri ona teslim

${ }^{22}$ D. K. Kouymjian, A Numismatic History of Southeastern Caucasia and Adharbaijan Based on the Islamic Coinage of the 5th/11th to 7th/13th Centuries, New York, 1969, 94.

${ }^{23}$ ibnu'l-Ezrak, a.g.e., s. 36; Çovreba, a.g.e., s. 324; Vartabet, a.g.e., s. 195; H. Kayhan, Irak Selçukluları, Konya, 2001, 96.

24 ibnu'l-Ezrak, a.g.e., s. 34; ibnu'l-Esîr, a.g.e., s. 567.

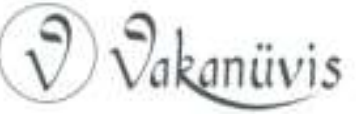


etmişlerdi (20 Ağustos 1124). ${ }^{25}$ Kral David'in Ani gibi önemli bir ticaret şehrini ele geçirmek istemesi yadırganacak bir girişim olmasa gerektir.

Ticareti ön plana alan bu politikanın IV. David'den sonraki kral ve kraliçeler tarafından da devam ettirildiği görülmektedir. Bu dönemde bastırılan bütün paralar İslâmi tarzda tanzim edilmiştir. Bunun ekonomik amaçlarla yapıldığı, zengin Müslüman ülkelerin Kafkaslardaki güçlü ticari varlıklarını devam ettirmelerini sağlamak için böyle bir yola başvurulduğu açıktır. Bunu Gürcü Krallığı'nın Irak Selçukluları veya Azerbaycan Atabeyliğine tâbi olduğu şeklinde yorumlamak ise yanlıştır. Kral III. Giorgi'nin bastırdığı paralarda onun Irak Selçukluları Devletine tâbi olduğuna dair bir ifade yoktur. ${ }^{26}$ Keza, Kraliçe Tamara, Kral Giorgi Laşa ve Kraliçe Rosudan'ın (1223-1247) paralarında da onların herhangi bir devlete tâbi olduğuna dair ifade bulunmamaktadır. ${ }^{27}$ İslami tarz paraların tedavülde tutulması, ticaretin Müslümanlar tarafından yürütüldüğünü ortaya koymaktadır.

\section{Atabey Ildeniz'in Gürcülerle İlişkileri}

Kral III. Bagrat (1156-1184), illdeniz'in Irak'taki uzun süreli meşguliyetinden istifade ederek Doğu Anadolu'ya bir sefer yapmıştı. Ahlatşahlar Devleti hükümdarı II. Sökmen'in elinde bulunan Kars ve civarındaki bazı yerleri eline geçirdikten sonra harekâtını Ağrı dağı eteklerine, muhtemelen Gence'ye kadar ilerletti ve burayı ele geçirdi (1161). Aynı yıl içerisinde müstahkem Ani üzerine yürüyen kral, Şeddâdî hükümdarı II. Fadlun'a (1155-1161) karşı ayaklanma çıkararak onu yenilgiye uğratıp, Sürmari'de bulunan Bekrân adındaki kaleye kaçmasını sağlayan papazların elinden şehri teslim aldı (HaziranTemmuz 1161). Kral şehirde oldukça büyük bir katliam yaparak, en az bin kişiyi öldürüp, bütün şehri de yağmaladıktan sonra, buraya 2 bin seçme savaş̧̧ı bırakarak, şehrin idaresine Prens Sadun'u tayin etti.

${ }^{25}$ Çovreba, a.g.e., s. 324; Vardan, a.g.e., s. 195-196; Urfalı Mateos, a.g.e., s. 279; V. Minorsky, a.g.e., s. 84; O. Turan, Selçuklular Zamanında Türkiye,165; W. E. D. Allen, 100.

${ }^{26}$ David M. Lang, Studies in the Numismatic History of Georgia and Transcaucasia, NY, 1955, 20-22; Irakli Paghava, Vlastimil Novak, "Georgian coins in the collection of The National Museum-Naprstek Museum in Prague", Annals of The Náprstek Museum, 34/2, 2013, 46-47.

${ }^{27}$ Lang, a.g.e., s. 22-33; Irakli Paghava, Vlastimil Novak, 47-50.

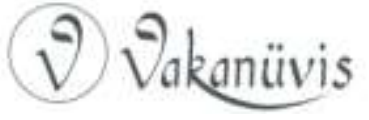


Bunun akabinde Şeddâdî hanedanına mensup olanları tutuklatıp yanına alarak, Tiflis'e geri döndü. ${ }^{28}$

Gürcü saldırıları bundan sonra da devam etti. Kral III. Bagrat, Temmuz-Ağustos 1162 tarihinde 30 bin kişilik büyük bir ordu ile Azerbaycan'a girerek, Duvin şehri üzerine yürüdüler. Burayı işgal eden Gürcüler, şehir ve çevresini yağmalayıp, 10 bini aşkın insanı kılıçtan geçirdiler. Kılıçlardan kurtulabilenler de esir alındı. Esirler arasında bulunan kadınları çırılçıplak soyarak götürdüler. ${ }^{29}$ Bir Ermeni kaynağına göre, esirlerin sayısı 60 bini bulmaktaydı. ${ }^{30}$

Illdeniz, Gürcülerin yaptıkları bu saldırıyı haber aldıktan sonra gerekli tedbirleri almak ve karşı harekette bulunmak amacıyla Azrebaycan ve Arran 'a dönmeye karar verdi. İlk iş olarak da Erdebil'in yönetimini komutanlarından Muhammed b. Akkuş'tan alarak oğlu Cihan Pehlivan'a verdi. Azerbaycan'a ulaşan İldeniz, Gence ve Beylekan'dan daha önceden alınan vergilerin tekrar kendisine verilmesi için istekte bulunan Gürcü kralının elçileri ile karşılaştı. Bu isteklere karşı cevaben, "Tiflis'i muhasara ile zaptetmek" niyeti ile Azrebaycan'a geldiğini ve aralarındaki kozu silahla paylaşacaklarını kesin bir şekilde Gürcü kralına iletti. Ayrıca durumu bir mektupla Sultan Arslanşah'a bildirdi. Bunun üzerine sultan, son derece büyük bir ordu topladı ve harekete geçti. Selçuklu ordusu Nahcivan'a geldiği zaman orada hazır bekleyen ildeniz'in ordusuyla buluştu. Burada Ahlatşahlar hükümdarı II. Sökmen, Merâga hâkimi Arslanaba ve Erzen hâkimi Fahreddin Devletşah orduları ile gelerek sultana katıldılar. Birkaç gün burada kalındı.

${ }^{28}$ Çovreba, a.g.e., s. 343-345; i̇bnu'l-Ezrak, a.g.e., s. 127; ỉbnu'l-Esîr, a.g.e., XI, s. 228; Râvendî, a.g.e., II, s. 274; Urfalı Mateos, a.g.e., s. 331; Vardan Vartabet, a.g.e., s. 205; Abû'l-Farac, Abû'l-Farac Tarihi, çev. Ö. R. Doğrul, Ankara, 1987, II, 398-399; Anili Kadı Burhaneddin, Enîsu'l-Kulûb, Kısmen nşr. F. Köprülü, "Anadolu Selçuklu Tarihinin Yerli Kaynakları", Belleten, VII/27, Temmuz, 1943, 466; Smbat Sparapet, Chronicle, Translated from Classical Armenian by Robert Bedrosian, Long Branch, New Jersey, 2005, 84; Kesrevî-i Tebrizî, III, 70-71; O. Turan, Doğu Anadolu Türk Devletleri Tarihi, İstanbul, 1980, 94; A. C. S. Peacock, "Georgia and the Anatolian Turks in the 12th and 13th Centuries", Anatolian Studies, Vol. 56 (2006), 130.

${ }^{29}$ İbnu'l-Esîr, a.g.e., XI, s. 234; i̇bnu'l-Ezrak, a.g.e., s. 130; Ebû'l-Fidâ, el-Muhtasar fi Ahbâri'l-Beşer, Nşr. M. Dayyûb, Beyrut, 1997, II, 113.

${ }^{30}$ Anili Samuel, a.g.y., II, s. 464-465.

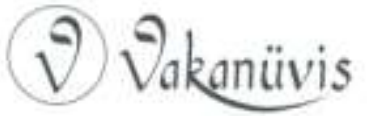


Selçuklu hükümdarının faaliyetlerinden haberdar olan Gürcü kralı, böyle büyük bir güce karşı koyamayacağını gördüğünden, elçi yollayarak 'bütün isteklerinden vaz geçtiğini ve sultana tâbi olduğunu' bildirip, barış talebinde bulundu. Arslanşah ve ildeniz, durumu devlet adamları ve komutanlarla müzakere ettikten sonra, barış talebini reddederek, Gürcülerle savaş yapmaya ve onların Türklere yaptıkları mezâlimin intikamını almaya karar verdiler. Gelen Gürcü elçisi yumuşak sözlerle uğurlandıktan sonra orduyla birlikte Nahcivan'dan harekete geçtiler. Bu sırada sefere çıkan ordunun içerisinde çok sayıda Türkmen gönüllü de bulunuyordu. Bunlar Gürcülerden intikamlarını almak için sultanın ordusuyla birlikte sefere çıkmışlardı. Ordunun mevcudu 50 bini geçmişti.

Selçuklu sultanının sefere çıkmasını barış yoluyla engelleyemeyen Kral Bagrat, onu karşılamak için hazırlıklarını sıklaştırdı ve mükemmel bir şekilde donatılmış oldukça büyük bir ordu topladı.

Birleşik Türk kuvvetleri Gürcistan topraklarına girerek, ilk olarak Duvin'in kuzeyinde bulunan Merian şehrine saldırmak suretiyle burayı tahrip ettiler ve yaklaşık 4 bin Ermeni ile Gürcü burada maktul düştü. Buradan Artaskh eyaletinde bulunan Aşnag kasabası tahrip edildi. Hareketlerine devam eden Türk kuvvetleri Somakhet'e vararak Gag kalesini tahrip ettiler. Burada karargâh kurarak, üzerlerine gelmekte olan Gürcü kralının ordusunu karşılamağa hazırlandılar.

íki ordu karşılaştıklarında oldukça şiddetli bir savaşa tutuştular. Her iki tarafın da kaybı büyük oldu. Türk ordusunun büyük saldırı gücü karşısında dayanamayacağını anlayan Gürcü kralı dayanamayarak savaş alanından kaçtı ve ormanda izini kaybettirdi. Başsız kalan Gürcü ordusu bozgun halinde dağıldı (13 Temmuz 1163). Türkler kaçanları uzun bir süre takip ettiler. Yaklaşık 10 bin Gürcü askeri savaş alanında maktul düştü. Bu sayının çok daha fazlası esir alındı. Gürcü ordusunun bütün ağırlıkları ve kralın servetleri savaş alanında Türklerin eline geçti. $^{31} \mathrm{Bu}$ zaferin duyulmasıyla birlikte bütün Türk şehirlerinde

\footnotetext{
${ }^{31}$ ibnu'I-Ezrak, a.g.e., s. 134; Hüseynî, a.g.e., s. 110-114; İbnu'I-Esîr, a.g.e., XI, s. 234235; Çovreba, a.g.e., s. 345-351; Vartabet, a.g.e., s. 205-206; İbn Kesîr, a.g.e., XII, s. 444; Anili Samuel, a.g.y.; Mikhitar Goş, Kronik, İng. tr. C. J. F. Dowsett, "The Albanian chronicle of Mxitar Gos", BSOAS, v. XXI, No.1/3, (1958), 489-490; Müneccimbaşı Ahmed b. Lütfullah, Câmiu'd-Duvel, Çev. A. Öngül, Selçuklular Tarihi I. Horasan-Irak,
} 
bayramlar yapıldı. Şehirler süslenerek, günlerce süren zafer şenlikleri tertiplenip, yoksullar için hayvanlar kurban edildi. ${ }^{32}$

$\mathrm{Bu}$ savaşı takiben Ani Türkler tarafından muhasara edildi ve Gürcüler tarafından boşaltılarak Türklere terk edildi (Mart-Nisan 1164). Şehre giren IIldeniz, Gence önlerine kadar Gürcüleri takip etti. Şehirde bir müddet kalarak düzene soktu ve Gürcüler tarafından yapılan tahribat sonucu harabe haline gelen şehri eski çehresine kavuşturmak için yoğun bir imar faaliyetine girişti. Bu arada, Gürcü işgali sırasında kaçan şehir halkı tekrar geriye döndüler ve yakılıp-yıkılan şehirlerinin onarılmasına yardım ettiler. İldeniz bu faaliyetlere yılsonuna kadar devam etti ve bittiği zaman Ani'yi eski sahipleri olan Şeddâdîlerden Emîr Şehinşah (1163-1199)'a teslim etti ve şehirden ayrıldı. ${ }^{33}$

Gürcü Kralı III. Giorgi, Irak Selçukluları hükümdarı Arslanşah ile aralarındaki düşmanca ilişkileri düzeltmek ve barış sağlamak amacıyla Selçuklu ailesinden bir melikin karısı olan kızkardeşi Rusudan ile Atabeg İldeniz'in arabuluculuğuna başvurmak zorunda kaldı. ${ }^{34}$

"Kral Giorgi, ara sıra generallerini ve askerlerini gâh Nahcivan kapılarına, gâh Masis dağına ve Gagvam'a, Berdea ve Balkun'a kadar sevk ediyordu. Kendisi de zevk ve eğlence ile vakit geçiriyordu". ${ }^{35}$ Gürcüler, bu saldırıların birinde, 561/1165-66 yılında büyük bir orduyla Buldân üzerine baskın düzenlediler ve saldırılarını Gence'ye kadar genişlettiler. Bu saldırıları sonucunda Müslüman halktan yüzlerce kişi öldürüldügü gibi, başta kadınlar olmak üzere yüzlercesi de esir alındı.

Kirman ve Suriye Selçukluları, İzmir, 2000, 192; Step'annos Orbelean, History of the State of Sisakan, Translated from Classical Armenian by Robert Bedrosian, To the memory of my grandmother Aghavni Postoian Torigian, Sources of the Armenian Tradition, Long Branch, New Jersey, 2012-15, 198; Turan, a.g.e., s. 94; Kırzıoğlu, a.g.e., s. 126; Allen, a.g.e., s. 102; H. Alyârî, Azerbaycan Atabeyleri II-Deniz Oğulları, İstanbul Üniversitesi Edebiyat Fakültesi, Basılmamış Doktora Tezi, İstanbul, 1966, 35-36.

32 ibnü'l-Ezrak, a.g.e., s. 134-135. Müellif, zaferden iki gün sonra Ahlat'ta halkın, kendisinin de hazır bulunduğu büyük bir eğlence tertip ettiklerini, 300 baş hayvan keserek yoksullara dağıttıklarını belirtmektedir.

33 ibnu'l-Ezrak, a.g.e., s. 140. Yine bu yıl içerisinde Sürmari hâkimi Emîr İbrahim Gürcülerle savaşarak, onları ağır bir yenilgiye uğratmış ve pek çoğunu öldürdükten sonra ileri gelen komutanlarını esir almıştı (bkz. a.g.y.).

${ }^{34}$ Çovreba, a.g.e., s. 352.

${ }^{35}$ Çovreba, a.g.e., s. 352.

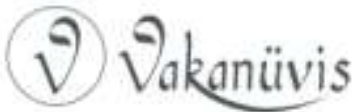


Ayrıca Müslümanların oturdukları kalelerin birçoğu tahrip edilerek, yağmalandı. ${ }^{36}$ Gürcülerin saldırılarının gittikçe sıklaşması üzerine, Azerbaycan'da bulunan Arslanşah'ın annesi 569/1173-74 yılının kış ayları ortasında kalkarak Hemedan'a gelmiş ve durumu oğluna şikayet ederek, acilen tedbir alınmasını istemişti. ${ }^{37}$

Ekim 1174 tarihinde Gürcü Kralı büyük bir ordu ile sefere çıkarak Ani'ye geldi ve şehri bir süre kuşatma altında tuttuktan sonra ele geçirdi. Şehir, ilk işgalde olduğu gibi Gürcüler tarafından büyük bir yağma ve kıyım hareketine uğratıldı. Ani'nin hâkimi olan Şeddâdî ailesinden Emîr Şehinşah esir edilerek Tiflis'e götürüldü ve bu bölge Gürcü krallığına bağlandı. ${ }^{38}$ Böylece bu müstahkem şehir Türkler tarafından geri alındıktan 10 yıl sonra tekrar Gürcülerin hâkimiyeti altına girmiş oldu.

Ani'nin kaybedilmesi üzerine harekete geçen illdeniz, Gürcüler karşısında yenilgiye uğradı ve Azerbaycan'da tekrar büyük bir ordu toplayıp geri döndü. Evin ovasında onlarla karşılaşmasına rağmen iki taraf da birbirlerine saldırmaya cesaret edemediği için aralarında savaş olmadı. Gürcü ordusunun geri çekilmesinden sonra illdeniz Nahcivan'a geri döndü. Gürcüler karşısında kesin bir netice alabilmek için büyük hazırlıklar içerisine girerek, tekrar asker toplamağa başladı. Ayrıca, başta Ahlat hâkimi Sökmen olmak üzere, Anadolu Türk beylerine elçiler göndererek, Gürcüler üzerine yapacağı büyük sefer için ordularıyla birlikte yardıma gelmelerini istedi. ${ }^{39}$

İldeniz'in teşvikleriyle Gürcistan üzerine bir sefer yapmağa razı olan Sultan Arslanşah, sefer sırasında Nahcivan yakınlarında bulunan Pârsîbâzâr çayırlığında illdeniz ve oğullarının güçleriyle buluştuktan sonra hastalandı. Hastalığının iyileşmesi için üç gün boyunca tedavi görmesine rağmen bir türlü iyileşemeyince, yanında bulunan annesiyle birlikte Kiliya kalesine, oradan da Duvin'e gitti. Burada 40 gün kaldıktan

\footnotetext{
${ }^{36}$ ibnu'l-Esîr, a.g.e., s. XI, 262.

${ }^{37}$ Râvendî, II, a.g.e., s. 284.

38 ibnu'l-Ezrak, a.g.e., s. 168 vd.; Vardan Vartabet, 208. Süryani Mihail, Ani'nin Gürcülerin işgaline uğradığı tarihi 1175 olarak göstermektedir (bkz. Süryani Mihail, Vekayinâme, ikinci Kısım (1042-1195), Çev. H. D. Andreasyan, 1944 (TTK Kütüphanesi'nde bulunan basılmamış tercüme), 236).

${ }^{39}$ ibnu'l-Ezrak, a.g.e., s. 173; Kırzıoğlu, a.g.e., s. 128.
}

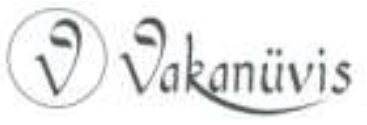


sonra veba hastalığının başladığı Aras nehri kıyılarını takip ederek Nahcivan'a vardı. Bu yolculuk sırasında, veba salgınından etkilenen Selçuklu ordusu bir hayli zayiat verdi.

İldeniz'in, Türk beyleriyle vardığı mutabakat gereği, oğulları Cihan Pehlivan ve Kızıl Arslan komutasındaki birliklerle, Anadolu Türk beylerinden Ahlatşah II. Sökmen ve Diyarbakır Artuklu hükümdarı Nureddin Muhammed b. Kara Arslan'ın kuvvetleriyle, Beğdili Türkmenlerinden oluşan büyük bir ordu Nahcivan önlerinde toplandılar (Temmuz-Ağustos 1175). Buradan hareketle Gürcistan'a girip Lori ve Domanis'i geçerek Ahalkelek ve Tiryâlis sahrası arasında bulunan müstahkem Akşehir'e geldiler. Buraya saldırarak şehri ve çevresinde bulunan köyleri yağmaladılar; halkını esir edip, ekinlerle birlikte her tarafı tahrip ettiler. Bu kadar büyük bir ordunun karşısına çıkmaya cesaret edemeyen Gürcü kralı Giorgi, tehlike geçene kadar sık ormanlarla kaplı bölgelere çekilmeyi tercih etti. Karşılarında savaşacak bir güç bulamayan Türk ordusu geri döndü. ${ }^{40}$ Nahcivan'da kalarak, burada Gürcü topraklarına giren Illdeniz ve Türk beylerini bekleyen Arslanşah, onların başarıyla geri dönmesinden sonra Ahlat hâkimi Sökmen ve diğer Türk beyleri ile emîrleri başarılarından dolayı kutlayıp, hil'atler giydirdikten sonra 50 günlük bir ikâmetin ardından Hemedan'a doğru hareket etti. Arslanşah bir daha böyle bir sefere çıkma imkânını bulamadı. Türk beyleri de ülkelerine geri dönerek, 19-29 Eylül 1175 tarihinde zafer şenlikleri ve kutlamaların yapıldığı Ahlat'a ulaştılar. ${ }^{41}$ Gürcülerin eline geçen Ani şehri Türkler tarafından kuşatılmasına rağmen geri alınamadı. ${ }^{42}$

\footnotetext{
${ }^{40}$ ibnu'l-Ezrak, a.g.e., s. 181; Râvendî, a.g.e., s. II, 284-285; Zahîreddîn Nişâbûrî, Târîh-i Âl-i Selçuk, Nşr. İ. Afşar, Tahran, 1332, 81 vd.; Reşîdeddîn, a.g.e., s. 173-174; Hamdullah Mustevfî Kazvînî, Târîh-i Guzîde, Nşr. E. G. Browne, London, 1910, I, 473; F. Sümer, Selçuklular Devrinde Doğu Anadolu'da Türk Beylikleri, Ankara, 1990, 75; Yinanç, a.g.m., 614. Fars kaynaklarına göre, bu sefer 569/1173-1174 tarihinde yapılmıştı ve ildeniz ile Türk beyleri, Gürcü kralının ordusuyla Akşehir civarında karşılaşmış ve yenilgiye uğratarak, bu şehri ele geçirdikten sonra Duvin şehrinin intikamını almak için burayı yakmışlardı.

${ }^{41}$ ibnu'l-Ezrak, a.g.y.

${ }^{42}$ Vardan Vartabet, Türklerin Ani'yi kuşatmaları sırasında zor durumda kaldığı anlaşılan vali İvane tarafından şehrin Türklere teslim edilmek istenmesine rağmen, 'şehir halkı bundan haberdar olarak ona göre tedbir aldılar' ve şehri teslim etmediler (bk. 208).
}

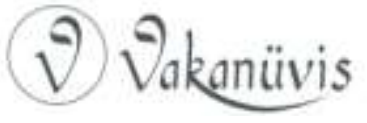


Atabey Illdeniz, 35 yıllık atabeylik döneminde Kafkaslarda, Doğu Anadolu ve Azerbaycan'da Türk varlığı için ciddi bir tehlike olan Gürcü Krallı̆ı'nı durdurmuş, yaptığı seferlerle tehdidi engellemişti. Bu dönemde Kafkaslarda ciddi bir Türk yerleşimi olduğu ve IIldeniz'in bunlardan çok yararlandığı anlaşılmaktadır. İldeniz'in Sultan Mesud'a yazdığı bir mektupta: "Eğer düşmana karşı gitmem istenirse giderim ve etrafıma Türkmenlerden istediğim kadar toplayabilirim." demekteydi. ${ }^{43}$ Bu ifade, Kafkasya'ya Türk yerleşiminin ne kadar yüksek olduğunu gösterdiği kadar, İldeniz'in Türkmenler tarafından çok sevildiğini ve takdir gördüğünü de ortaya koymaktadır. IIdeniz'in Azerbaycan'ın en büyük askeri gücünü oluşturarak, her an emrine hazır 50 bin kişilik büyük bir askeri güç oluşturarak, ${ }^{44}$ bu kuvvetleriyle bölgeye yapılan Gürcü-Kıpçak saldırılarını püskürtmesi, Kafkaslardaki Türkmen varlığının bir başka göstergesi olsa gerektir.

\section{Atabey Cihan Pehlivan'ın Gürcülerle Iilişkileri}

Sultan Arslanşah'ın vefatı ile Irak Selçukluları tahtına küçük yaştaki oğlu II. Tuğrul geçmişti. Devletin kontrolü sultanın vesayetini elinde tutan Atabey Cihan Pehlivan'ın (1175-1186) ellerinde idi. Çocuk yaştaki bir hükümdarın Irak Selçukluları Devleti'nin başına geçmesini ve Atabeg Cihan Pehlivan'ın Hemedan'da bulunmasını fırsat bilen Gürcü kralı Azerbaycan'a saldırdı ise de hemen karşılık gördü. Büyük bir orduyla mukabil saldırıya geçen Cihan Pehlivan, Azerbaycan ve Arran üzerinden Gürcü ülkesine girdi ve onları bozguna uğratıp, barış istemek zorunda bıraktı. Gürcü kralının elçileri Cihan Pehlivan'ın şartlarını kabul ederek ülkelerine geri döndüler. Saldırgan Gürcü birliklerini bozguna uğratıp geri püskürttükten sonra kardeşi Kızıl Arslan'ı Azerbaycan ve Arran'da yerine vekil olarak bırakan Cihan Pehlivan Hemedan'a geri döndü. ${ }^{45}$ Bu olaydan sonra Cihan Pehlivan'ın ölümüne kadar başka bir Gürcü saldırısı olmadı.

Gürcistan'da en yüksek askeri görevleri işgal eden ve devletin önemli bölgelerini yöneten zengin Orbelyan ailesi 1176 yılında Bizans Imparatoru Manuel Komnen'in saflarında II. Kılıç Arslan'a yenilip,

\footnotetext{
${ }^{43}$ Hüseynî, a.g.e., s. 90.

${ }^{44}$ íbnu'l-Esîr, el-Kâmil fî't-Târîh, çev. A. Özaydın, A. Ağırakça, İslâm Tarihi, ibnu'l-Esîr, el-Kâmil fi't-Târîh Tercümesi, İstanbul, 1987, XI, 312.

${ }^{45}$ Hüseynî, a.g.e., s. 120; Hamdullah Mustevfî Kazvînî, a.g.e., s. 473-474.
}

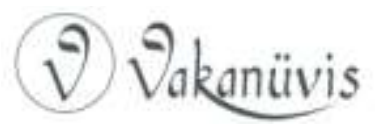


ortadan kaldııılmışlardı. Kalanları ise Kral III. Giorgi'ye karşı büyük bir isyan başlatmış olmalarına rağmen, Kıpçak komutan Kubasar'ın krala yardımı ile yenilgiye uğratılmışlar ve tamamen yok edilmiş, bütün mal ve mülklerine Kıpçak komutanlar tarafından el konulmuştu (1177). ${ }^{46}$ Kubasar, bu başarısı ile Gürcü devletinin başkomutanlığına getirtilmişti. Onun görevde kaldığı dönem içerisinde Gürcüler Türk topraklarına saldırıda bulunmamıştı. Bu durum Irak Selçukluları Devleti'nin son zamanlarına kadar bu şekilde devam etti.

Atabey Cihan Pehlivan, babasının politikasını devam ettirmiş ve Gürcüleri etkisiz hale getirmeyi başarmıştı.

\section{Atabey Kızıl Arslan'ın Gürcülerle iliş̧ileri}

Kral Giorgi (1156-84) son yıllarında bazı iç sorunlarla uğraşmıştı. Ancak kızı Kraliçe Tamara (1184-1213) zamanında yeni istilalarla Gürcistan'ın servetleri zirveye ulaştı. Tamara'nın zaferleri gerçekte generalleri Zak'are ve Ivane'ye aitti. ${ }^{47}$

Atabey Kızıl Arslan (1186-1191) zamanında Gürcülerle ilişkiler devam etti. Bu dönemde Gürcü tahtında bulunan Kraliçe Tamara, babası Rus çarı Andre'nin ölümünden sonra amcası Vsevolod tarafından Kıpçak şehri Sevinç'e sürgün edilen George Bogolyubskoi ile evlenmişti. Bu sırada Türkler Çıldır Gölü civarına akın yapmışlardı. Gürcü komutanı Gamrasel Kahas-Dze onlara saldırmış ve yenilgiye uğratarak bölgeden uzaklaştırmıştı. Aynı anda Erzurum'dan gelen Saltuklu ve Germiyan Türkleri atlı ve yaya olarak Klarcet'i istila etmişlerdi. Gürcü ordusu bunların üzerine yürüyerek bunları yenilgiye uğratıp, püskürtmüştü. Bundan sonra Gürcü ordusu Duvin'e saldırarak yağmalayıp dönerken Duvin ve Surmari'deki Türk askerlerinin hücumuna uğramıştı. Gürcü ordusu kısa sürede kendisini toplayarak onları püskürtmüştü. Kraliçe Tamara'nın kocası Gürcü ordusunu toplayarak Duvin üzerine yürümüş ve burada büyük tahribatlarda bulunmuştu. O, bundan sonra Gelakun'a sefer yapmıştı. Burada yerleşmiş bulunan kalabalık Türkmen gurupları Gürcülerle mücadele etmelerine rağmen onlara yenilmekten kurtulamamışlardı. Rüstem,

${ }^{46}$ Çovreba, a.g.e., s. 358; Vartabet, a.g.e., s. 209; Manvelichvili, a.g.e., s. 178-181; Kırzıoğlu, a.g.e., s. 130-131.

${ }^{47}$ V. Minorsky, Studies in Caucasian History, London, 1953, 102.

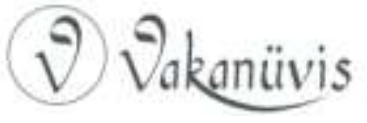


İlgazi ve Alpı komutasındaki Türkmenler karşı saldırıya geçerek Gürcü ordusuna saldırmışlar fakat yenilgiye uğramışlardı. Bundan sonra Gürcüler Gence'nin aşağısında Beylekan'a ve Ağrı Dağına kadar olan yerlere sefer yapmışlar ve her yeri yağmalayıp, tahrip etmişlerdi. ${ }^{48}$

Bütün bu gelişmelerden sonra Gürcülerle ilişkilerde dikkat çeken ilginç bir olay Kızıl Arslan'ın adı belirtilmeyen oğlunun Gürcü Kraliçesi Tamara'nın güzelliğinden etkilenerek ona âşık olması ve onunla evlenmek için dinini bile değiştirmek istemesi olmuştur. Atabey buna itiraz etmiş ve oğlunu engellemiştir. ${ }^{49}$

Atabey Kızıl Arslan, Irak Selçuklu Sultanı II. Tuğrul ile uğraşmaktan, Gürcülerle mücadeleye fırsat bulamamıştı. Bu da Gürcülere cesaret vermiş, Azerbaycan ve Doğu Anadolu'da saldırılarda bulunmalarına sebep olmuştu.

\section{Atabey Ebubekir'in Gürcülerle Iliş̧kileri}

Sultan II. Tuğrul'un 1194'te ölümüyle sona eren Irak Selçukluları Devletinin toprakları IIdenizliler arasında paylaşılamamış, Azerbaycan'a hâkim olan Ebubekir (1194-1211), kardeşleri Kutluğ İnanç Mahmud ve Emîr-i Emîrân Ömer'le mücadele etmişti. Yapılan mücadeleyi kazanan Ebubekir, kardeşlerini etkisiz hale getirmişti. Kutluğ İnanç Mahmud Irak'a halifenin yanına giderken, Emîr-i Emîrân Ömer ise Şirvanşah'a sığınmış ve onun kızıyla evlenerek, desteğini sağlamıştı. Durumunu biraz kuvvetlendirdikten sonra da Gürcü Kraliçesi Tamara'nın yanına gitmişti. Türklerle sonu gelmez bir mücadelenin içerisinde bulunan Gürcü kraliçesi, koz olarak kullanmak için onu iyi karşılamış ve yardımda bulunmuştu. Taraflar arasında bir anlaşma yapılmış ve Gürcüler, onu büyük bir orduyla Azerbaycan'a yollanışlardı. Emîr-i Emîrân Ömer burada Türkmenlerden asker toplayarak gücünü daha da arttırmış ve Atabey Ebubekir'in üzerine yürümüştü. Yapılan savaşta yenilgiye uğrayan Ebubekir hayatını güçlükle kurtararak Beylekan'a ve oradan da Nahcivan'a gitmişti. Çevreye dağılan askerleri ise sonradan gelip ona katılmışlardı.

\footnotetext{
${ }^{48}$ Çovreba, a.g.e., s. 368--370.

${ }^{49}$ Çovreba, a.g.e., s. 371. Bu oğul, Cihan Pehlivan'ın bir Türk kadından doğan ve çocuğu olmadığı için kardeşi Kızıl Arslan'a evlatlık verdiği Atabey Ebubekir olabilir (bkz. Hüseyni, a.g.e., s. 121).
}

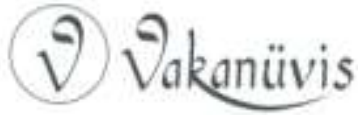


Emîr-i Emîrân Ömer, savunmasız kalan Azerbaycan'ı eline geçirmek için ileri harekâta devam ederek Gence'yi kuşatmıştı. Yanında bulunan Gürcü askerlerinden korkan halk şehirlerini teslim etmek istememişler, direnmişlerdi. Şehrin alınmasının çok zor olduğunu gören Emîr-i Emîrân Ömer, teslim olmaları halinde Gürcülerin çekip gideceklerine dair söz verince savunmacılar şehri kendisine teslim etmişlerdi. $O$, başşehir Gence'ye girerek, Ebubekir'in kaçması sonucu boş kalan Azerbaycan Atabeyliği tahtına oturdu. Varılan antlaşma gereğince şehre girmeyen Gürcüler ayrılıp, ülkelerine geri döndüler. Emîr-i Emîrân Ömer'in atabeyliği uzun sürmedi. Zira, bir ay içerisinde öldü. Bunun üzerine başsız kalan şehir halkı Ebubekir'e elçi yollayarak, onu şehirlerine davet ettiler. Bu yeni durum üzerine Gence'yi tekrar eline geçirmeyi başaran Ebubekir, şehrin yönetimini oğluna bıraktıktan sonra Nahcivan'a geri dönmüştü.

Emîr-i Emîrân Ömer'in vefat ettiğini ve sonrasında Gence'nin Ebubekir'in eline geçtiğini duyan Gürcüler, antlaşmanın bozulduğunu görerek büyük bir orduyla şehre saldırdılar. Bir çıkış hareketi ile onları püskürten Ebubekir'in oğlu, etkili bir savunma ile şehrin onların ellerine geçmesini önledi. Şehri ele geçiremeyeceklerini gören Gürcüler geri çekilerek Nahcivan üzerine yürüdüler. Gürcülere karşı kendini savunamayacağını düşünen Ebubekir, şehri terk ederek Tebriz'e gitti. Onu takip eden Gürcüler, burada da rahat bırakmayarak, çevrede bulunan köylere saldırdılar. Gürcülerin saldırılarından kurtulmanın imkânsızlığını gören annesi Zâhide Hatun, yüklü miktarda para vererek, saldırıların durmasını ve onların ülkelerine geri dönmelerini sağladı. ${ }^{50}$

Atabey Ebubekir, yönetimini güçlendirmek ve ülkesini dört bir taraftan kuşatan Gürcülerin tehdidini durdurmak için Arran'a yürümüştü. Gürcü kraliçesi Tamara'nın ordusu ile Şemkur civarında yaptığı savaşta yenilmekten kurtulamadı ve Şemkur, peşinden Gence Gürcülerin eline geçti (1194). ${ }^{51}$

${ }^{50}$ Hüseynî, a.g.e., s. 130-133; Çovreba, a.g.e., s. 392-396; Kırzıoğlu, a.g.e., s. 133-135; N. N. Şengeliya, "XI-XIII. yüzyıl Gürcü tarihçilerine göre Selçuklular", çev. M. Mürselov, Tarih incelemeleri Dergisi, XXII/2, Aralık 2007, 238.

${ }^{51}$ Çovreba, a.g.e., s. 391-394; Z. Bunyadov, Azerbaycan Atabeyleri Devleti 1136-1225, Baku, 2007, 84-85; M. Tsurtsumia, "The true cross in the armies of Georgia and the Frankish East”, Crusades, 12, 2013, 97.

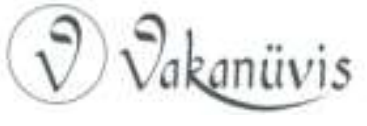


Atabey Ebubekir, Kraliçe Tamara'nın eski kocası Georgi'nin Arran'da yanına gelip, kendisinden yardım istemesi üzerine onu Gence emîri tayin etmiş, emrine verdiği askerlerle Gürcistan'a sefere göndermişti. Georgi, Gence ve Arran askerleri ile Kambeçovani (Kahetiya)'ye saldırmış, her yeri yağmalamış, tarlaları tahrip etmiş, çok sayıda esir ve ganimet alarak geri dönmüştü (1196). ${ }^{52}$

Atabeg Ebubekir'in sonradan kendini içki ve eğlenceye kaptırması Gürcülere saldırı için gereken fırsatı yaratmış, bunun üzerine onlar Azerbaycan şehirlerine saldırmaya başlamışlardı. Nahcivan ve Beylekan'ı haraca kestikten sonra Duvin'i ve çevresindeki bir takım kaleleri ellerine geçirdiler. Buradan Merend'e saldırıp, burasını ve takiben bütün Arran'ı işgal ettiler. Bunun arkasından Şemkur'u ve Erdebil'i ele geçirerek tahrip ettiler (599/1202-1203). Bütün bu saldırılar olurken Atabeg Ebubekir onlara karşı harekete geçmeyerek, sarayında zevkü sefa ile meşgul olmaktaydı ve "hâcib ve emîrlerinin kendisine Gürcüler hakkında bir şey söylememelerini emretmişti. ${ }^{153} \mathrm{O}$, durumun gittikçe kötüye gittiğini görüyor, fakat bir türlü kötü alışkanlıklarını bırakamıyor, çevresinde bulunanlar da ona bu konuda yardımcı olmuyorlardı. Bu durum karşısında ülkesini koruyamayacağını görerek, Gürcü kralının kızıyla evlenerek, akrabalık kurmak suretiyle onların ülkesine saldırmalarını önledi ve verdikleri zararları bir müddet de olsa engellemeği başardı (602/1205-6). ${ }^{54}$

Gürcülerin saldırıları birkaç yıl sonra tekrar başladı. Ekim-Kasım 1210 'da Gürcü ordusu harekete geçerek sırasıyla Merend, Tebriz, Miyâne, Zencan, Kazvin, Ramcar ve Curcan'ı yağmaladılar. ${ }^{55}$ Görülmektedir ki, Azerbaycan Atabeyliği'nin Gürcü saldırılarından uzak kalan hiçbir yerleşim yeri kalmamıştır.

Kafkaslarda ardı arkası kesilmeden devam eden Gürcü Krallığı saldırılarının politik manevralarla etkisiz hale getirilmesinde Atabeg Ebubekir'in başarılı olduğunu söylemek mümkündür.

\footnotetext{
${ }^{52}$ Çovreba, a.g.e., s. 385; Allen, a.g.e., s. 105- vd.; Bunyadov, a.g.e., s. 74.

${ }^{53}$ Hüseynî, a.g.e., s. 133; İbnu'l-Esîr, a.g.e., XII, s. 156-157; Ebû'l-Fidâ, a.g.e., II, s. 195;

Kırzıoğlu, a.g.e., s. 132-135; Bunyadov, a.g.e., s. 89.

${ }^{54}$ ibnu'l-Esir, a.g.e., XII, s. 201; Ebû'l-Fidâ, a.g.e., II, s. 199.

${ }^{55}$ Çovreba, a.g.e., s. 417-419.
}

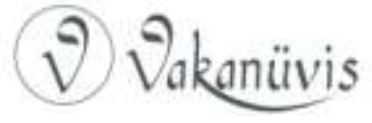




\section{Atabey Özbek'in Gürcülerle iliş̧kileri}

Atabey Özbek'in Azerbaycan'da hâkimiyetinin başladığı 1211'de Gürcü saldırıları hız kesmedi. Gürcüler Arran, İç Basaen, Barkuşat ve Malazgirt'e kadar saldırılarını yaygınlaştırarak Duvin, Gardman, Gence, Çarek, Hert, Şamkor, Kars, Vagharshakert, Kağızman, Surb Mari, Ani, Anberd, Becni, Garin, Partav ve Çaraberd'i ele geçirdiler. ${ }^{56}$

Saldırıların artması üzerine Atabey Özbek tâbi olduğu Harezmşah Muhammed'i (1200-1221) gelişmeler hakkında bilgilendirdi ve ülkesinin yağmalanması ile uğradığı ekonomik kayıplardan dolayı o yıl ödemesi gereken haracı ödeyemeyeceğini bildirdi. Harezmşah, Azerbaycan'daki gelişmeleri öğrenince Özbek'in haracını bağışladı ve Gürcü Kralı IV. Georgi (1210-1223)'ye mektup yazarak Azerbaycan'a saldırılarını durdurmasını istedi. Ciddiyetini göstermek için de elli bin kişilik bir ordu hazırladı. Durumdan haberdar olan Gürcü kralı elçi göndererek sultanı seferden vazgeçirmeğe çalıştı. ${ }^{57}$

Moğolların saldırıları sonucunda bir hayli zarar gören Arran bölgesindeki Beylekan şehri, çevreye dağılan halkının geriye dönmesinden sonra yeniden onarılmıştı. Onların bu meşguliyetlerinden istifade eden Gürcüler ani bir saldırı ile şehre girdiler ve ele geçirdiler. Moğolların yarım bıraktığı işi tamamladılar ve halkın tamamını kılıçtan geçirip, şehri tahrip ettiler (Ekim-Kasım 1222). Bütün bu işler olurken Atabey Özbek Tebriz'de zevk ve eğlenceyle dolu günler geçirmekte, olaylara seyirci kalmaktaydı. ${ }^{58}$

Kartlis Çovreba'nın belirttiğine göre, Gürcü Kralı IV. Giorgi, Gencelilerin kendi hâkimiyetine karşı ayaklanarak, ödedikleri yıllık vergiyi kesmeleri üzerine bir sefer düzenleyerek halkını itaate mecbur etmişti. $^{59}$

Atabey Özbek, o kadar çaresiz bir duruma düşmüştü ki, ödediği haracı geri vermesi için Gürcü kralına yalvarmış, bunun üzerine kral

\footnotetext{
${ }^{56}$ Orbelean, a.g.e., s. 202.

57 Nesevî, Sîretu Celâleddin Mengüberti, Nşr. H. A. Hamdi, Kahire, 1953, 58-59; Bunyadov, a.g.e., s. 98; Tsurtsumia, a.g.e., s. 99.

58 ibnu'l-Esîr, a.g.e., XII, s. 371; Kartlıs Tskhovreba, A Hıstory of Georgia, Edit. Roin Met'reveli, Stephen Jones, Tiblisi, 2014, 316.

${ }^{59}$ Çovreba, a.g.e., s. 426.
} 
onun vergisini almadığı gibi, ona değerli hediyeler vermiş ve aldığı tutsakları da serbest bırakmıştı. ${ }^{60}$

Gence halkı IV. Giorgi'nin ölümünden bir müddet sonra tekrar ayaklanmışlardı. Bunun üzerine Gürcüler 1225 yılında bir sefer yaparak şehri tekrar kuşattılar. Gence oldukça müstahkem bir kaleye sahipti ve halkı Gürcülerle yapılan uzun süreli savaşlar neticesinde oldukça tecrübe kazanmış olduğundan, bu ani Gürcü hücumunu yaptıkları çıkış hareketleriyle başarısızlığa uğrattılar. Şehri ele geçirmenin ve Gence halkı ile savaşmanın imkânsız olduğunu gören Gürcüler, ağır zayiatlar vererek geri çekildiler. ${ }^{61}$

Gence yenilgisinden sonra Gürcüler daha büyük bir ordu ile Azerbaycan'a saldırdılar. Amaçları Atabey Özbek'in elinde bulunan bütün şehirleri ele geçirmekti. Birer kişilik sıra halinde geçilebilecek kadar dar olan bir dağ geçidinden geçerken, daha önceden burada pusu kurmuş bulunan Atabey Özbek'in askerlerinin ani saldırısı ile Gürcü ordusu bozguna uğratıldı. Bunların büyük bir kısmı bu geçitte telef oldular. Ancak çok az bir asker kaçıp, canını kurtarabildi (1225). $\mathrm{Bu}$ büyük yenilgi Gürcülere oldukça dokunmuş ve Türkleri Azerbaycan'dan kovmak için daha ciddi bir şekilde hazırlanmağa başlamışlardı. Tam bu sıralarda Moğolların önünden kaçan Harezmşah Celâleddin Mengüberti'nin ordusuyla Merâga'ya ulaştığı haberinin gelmesi üzerine büyük bir tehlikenin kapılarına dayanmış olduğunu gören Gürcüler, Atabey Özbek'e haber göndererek Harezmşahlara karşı koyabilmek için güçlerini birleştirmeği teklif ettiler. Ancak durumdan haberi olan Harezmşah, taraflar arasında bir ittifak anlaşması yapılmadan önce bölgeye vararak, taraflarla tek tek hesaplaşmayı çıkarlarına daha uygun buldu. ${ }^{62}$

Atabey Özbek, eğlence alışanlığından taviz vermeyerek ülkesini Gürcüler, Harezmşahlar ve Moğolların saldırılarına karşı korumak için yeterli tedbir almamış, bilakis bu müstevlilere tâbi olarak ve onlara değerli hediyeler göndererek saldırılarını engellemeğe çalışmış, fakat başarılı olamamıştır.

\footnotetext{
${ }^{60}$ Tskhovreba, a.g.e., s. 316.

61 ibnu'l-Esîr, a.g.e., XII, s. 385.

62 ibnu'l-Esîr, a.g.e., XII, s. 391.
} 


\section{Sonuç}

Azerbaycan Atabeyliği, Kafkaslar bölgesinde Türk hâkimiyetini 85 yıl boyunca ayakta tutmuştur. Bu zaman zarfında Kafkasların güçlü devleti Gürcü Krallığı ile genelde savaşa dayalı ilişkiler yürütüldü. Gürcistan'ın yayılmacı politikaları Kafkaslarda bitmeyen mücadeleler yaşanmasına sebep olurken, diğer yandan da göze pek çarpmamakla birlikte sosyal, kültürel ve ekonomik ilişkiler tabii seyrinde canlı olarak devam etmekteydi. Büyük Selçuklular ve ondan yaklaşık yarım asır sonra Irak Selçuklularının tarih sahnesinden çekilmesi Ortadoğu'da genel bir asayişsizliğin ortaya çıkmasına zemin hazırlarken, bu durumdan en fazla etkilenen alanlardan birisi olarak Kafkaslar ön plana çıkmakta idi. Mevcut istikrarsızlığa Azerbaycan atabeylerinin son tesilcilerinin basiretsizlikleri de eklenince, üzerindeki baskı ortadan kalkan Gürcü Krallı̆ı Kafkaslar ve çevresindeki alanlarda muazzam bir genişleme politikası yürüttüler. Ancak, Harezmşah Celaleddin Mengüberti'nin ve peşinden de Moğolların bölgeye gelmeleri Gürcü ilerlemesini önledi.

\section{Kaynakça}

Abû'l-Farac, Abû'I-Farac Tarihi, çev. Ö. R. Doğrul, 2 cild, Ankara, 1987.

Allen, W. E. D., A History of The Georgian People, London, 1932.

Alyârî, H., Azerbaycan Atabeyleri II-Deniz Oğulları, İstanbul Üniversitesi Edebiyat Fakültesi, Basılmamış Doktora Tezi, İstanbul, 1966.

Anili Kadı Burhaneddin, Enîsu'I-Kulûb, Kısmen nşr. F. Köprülü, "Anadolu Selçuklu tarihinin yerli kaynakları", Belleten, VII/27, Temmuz, 1943, 379-522.

Anili Samuel, Tables Chronologiques, Fr. tr. M. Brosset, Petersburg, 1876.

Azîmî, Târîhu'l-Azîmî, Azîmî Tarihi (Selçuklular Dönemiyle ilgili Bölümler), Nşr. ve çev. A. Sevim, Ankara, 1988.

el-Bundârî, Zubdeu'n-Nusra ve Nuhbetu'I-Usra, çev. K. Burslan, Irak ve Horasan Selçukluları Tarihi, ìstanbul, 1943.

Bunyadov, Z., Azerbaycan Atabeyleri Devleti 1136-1225, Baku, 2007.

Ebû'I-Fidâ, el-Muhtasar fi Ahbâri'l-Beşer, Nşr. M. Dayyûb, 2 cild, Beyrut, 1997.

Hamdullah Mustevfî Kazvînî, Târîh-i Guzîde, Nşr. E. G. Browne, I, London, 1910.

Hüseynî, Ahbârü'd-Devleti's-Selçukiyye, çev. N. Lugal, Ankara, 1943. 
Irakli Paghava, Vlastimil Novak, "Georgian coins in the collection of The National Museum-Naprstek Museum in Prague", Annals of The Náprstek Museum, 34/2, 2013.

İbn Kesîr, Büyük İslâm Tarihi, çev. M. Keskin, 15 cild, i̇stanbul, 1995.

İbnu'I-Adîm, Zubdetu'I-Haleb min Târîhi Haleb, Nşr. S. Dahhan, 3 cild, Dimaşk, 1951-71.

ibnu'I-Esîr, el-Kâmil fi't-Târîh, çev. A. Özaydın, A. Ağırakça, islâm Tarihi, ibnu'I-Esîr, el-Kâmil fi't-Târîh Tercümesi, 12 cild, İstanbul, 1987.

ibnu'I-Ezrak, Târîhu Meyyâfârikîn ve Âmid, çev. A. Savran,Meyyâfârikîn ve Âmid Tarihi (Artuklular Kısmı), Erzurum, 1992.

İbnu'I-Kalânisî, Zeyli Târîhi Dimaşk, Nşr. H. F. Amedroz, Beyrut, 1908.

Kartlıs Tskhovreba, A HIstory of Georgia, Edit. Roin Met'reveli and Stephen Jones, Tiblisi, 2014.

Kartlis Çovreba, Gürcistan Tarihi (Eski Çağlardan 1212 Yılına Kadar), çev. H. Andreasyan, Ankara, 2003.

Kayhan, H., "Azerbaycan Atabegleri ildenizliler (1141-1225)", Yeni Türkiye 72, Kafkaslar Özel Sayısı - II, Ankara, 2015, 769-787.

Kayhan, H., Irak Selçukluları, Konya, 2001.

Kesrevî-i Tebrizî, Şehr-i Yârân-ı Gumnâm, 3 cild, Tahran, 1307-1308.

Kırzıoğlu, F., Kars Tarihi I, İstanbul, 1953.

Kırzıoğlu, F., Yukarı Kür ve Çoruh Boylarında Kıpçaklar, Ankara, 1992.

Kouymjian, D. K., A Numismatic History of Southeastern Caucasia and Adharbaijan Based on the Islamic Coinage of the 5th/11th to 7th/13th Centuries, New York, 1969.

Lang, David M., Studies in the Numismatic History of Georgia and Transcaucasia, NY, 1955.

Manvelichvili, A., Histoire de Géorgie, Paris, 1951.

Mes'ûd b. Nâmdâr, Le Recueil Transcaucasien de Mas'ûd b. Nâmdâr (Debut du VI/XII siecle, Ed. V. Minorsky, C. Cahen, Extrait du Journal Asiatique, Paris, 1949.

Mikhitar Goş, Kronik, İng. tr. C. J. F. Dowsett, "The Albanian chronicle of Mxitar Gos", BSOAS, v. XXI, No.1/3, (1958), 472-490.

Minorsky, V., "Causacia in the History of Mayyafarikin", BSOAS, VIII/1, 1949, 27-35.

Minorsky, V., Studies in Caucasian History, London, 1953.

Minorsky, V., "Tiflis", IA, XII/1, 264-279.

Müneccimbaşı Ahmed b. Lütfullah, Câmiu'd-Duvel, Çev. A. Öngül, Selçuklular Tarihi I. Horasan-Irak, Kirman ve Suriye Selçukluları, İzmir, 2000.

Nesevî, Sîretu Celâleddin Mengüberti, Nşr. H. A. Hamdi, Kahire, 1953. 
Paghava, Irakli and Novak, Vlastimil, "Georgian coins in the collection of The National Museum-Naprstek Museum in Prague", Annals of The Náprstek Museum, 34/2, 2013, 41-82.

Peacock, A. C. S., "Georgia and the Anatolian Turks in the 12th and 13th Centuries", Anatolian Studies, Vol. 56 (2006), 127-146.

Râvendî, Râhatu's-Sudîr ve Âyeti's-Sûrûr, çev., A. Ateş, Râhatu's-Sudûr ve Âyeti's-Sûrûr (Gönüllerin Rahatı ve Sevinç Alâmeti), 2 cild, Ankara, 1957-60.

Reşîdeddîn Fazlullah, Câmiu't-Tevârih, Selçuklularla ilgili Kısmını Nşr. A. Ateş, Ankara, 1960.

Rewriting Caucasian History, The Medieval Armenian Adaptation of the Georgian Chronicles the Original Georgian Texts and the Armenian Adaptation, Eng. tr. Robert W. Thomson, Oxford, 1996.

Sevim, A., "Artukoğlu ilgâzi", Belleten, XXVI/104, (1962), 649-691.

Sıbt ibnu'l-Cevzî, Mir'atu'z-Zeman fi Târihi'l-A'yân, Yay. J. R. Jewett, Chicago, 1907.

Smbat Sparapet, Chronicle, Translated from Classical Armenian by Robert Bedrosian, Long Branch, New Jersey, 2005.

Step'annos Orbelean, History of the State of Sisakan, Translated from Classical Armenian by Robert Bedrosian, To the memory of my grandmother Aghavni Postoian Torigian, Sources of the Armenian Tradition, Long Branch, New Jersey, 2012-15.

Sümer, F., Selçuklular Devrinde Doğu Anadolu'da Türk Beylikleri, Ankara, 1990.

Süryani Mihail, Vekayinâme, ikinci KIsım (1042-1195), Çev. H. D. Andreasyan, 1944 (TTK Kütüphanesi'nde bulunan basılmamış tercüme).

Şengeliya, N. N., "XI-XIII. yüzyıl Gürcü tarihçilerine göre Selçuklular", çev. M. Mürselov, Tarih incelemeleri Dergisi, XXII/2, Aralık 2007, 227-240.

Târîh-i Âl-i Selçuk der Anatoli, Nşrr. A. Mîrâs, Tahran, 1377 h.ş.

Tellioğlu, i.., “Orta Çağ’da Türk-Gürcü münasebetlerini şekillendiren faktörler", 38. Icanas Uluslararası Asya ve Kuzey Afrika Çalışmaları Kongresi (10-15 Eylül 2007 Ankara), Doğubilim Çalışmaları, Bildiriler, VI, Ankara, 2009, 3077-3089.

Tsurtsumia, M., "The true cross in the armies of Georgia and the Frankish East", Crusades, 12, 2013, 91-102.

Turan, O., Doğu Anadolu Türk Devletleri Tarihi, İstanbul, 1980.

Turan, O., Selçuklular Tarihi ve Türk-Isslâm Medeniyeti, İstanbul, 1980.

Turan, O., Selçuklular Zamanında Türkiye Tarihi, İstanbul, 1984.

Urfalı Mateos, Urfalı Mateos Vekayi-nâmesi (952-1136) ve Papaz Grigor'un Zeyli (1136-1162), çev. H. D. Andreasyan, Ankara, 1987.

Vardan Vartabet, "Türk Fütuhatı Tarihi (889-1269)", çev. H. D. Andreasyan, TSD, I, İstanbul, 1937.

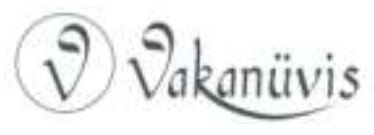


Yınanç, M. H., "Arslanşah", iA, I, 610-615.

Zahîreddin Nişaburî, Târîh-i Âl-i Selçuk, Nşr. İ. Afşar, Tahran, 1332. 